\title{
Variation of Static Frictional Forces in the Fixed Orthodontic System
}

\author{
ANCA OANA DRAGOMIRESCU ${ }^{1}$, ELINA TEODORESCU ${ }^{1}$, VIORICA TARMURE2*, ANDREEA BALUTA ${ }^{1}$, MARIANA PACURAR ${ }^{3}$, \\ DORIN NENOVICI ${ }^{4}$, MANUELA CHIBELEAN ${ }^{3}$, ECATERINA IONESCU ${ }^{1}$ \\ ${ }^{1}$ Carol Davila University of Medicine and Pharmacy, Faculty of Dental Medicine, Department of Orthodontics and Dentofacial \\ Orthopedics, 37 Dionisie Lupu Str,,020021, Bucharest, Romania \\ ${ }^{2}$ Iuliu Hatieganu University of Medicine and Pharmacy, Faculty of Dental Medicine, Department of Orthodontics, 8 Victor Babes \\ Str., 400012,Cluj Napoca, Romania \\ ${ }^{3}$ University of Medicine and Pharmacy, Science and Tehnology Targu Mures, Faculty of Dental Medicine, Department of \\ Orthodontics, 38 Gheorghe Marinescu Str., 540139 Tirgu Mures, Romania \\ ${ }^{4}$ Iuliu Hatieganu University of Medicine and Pharmacy, Faculty of Dental Medicine, Department of Oro-maxillo-surgery, 8 Victor \\ Babes Str., 400012,Cluj-Napoca, Romania

\begin{abstract}
Currently, the aesthetic appearance of fixed orthodontic appliances is an important factor for patients seeking orthodontic treatment. The aim of this study was to evaluate static frictional forces generated by different types of round $0.016^{\prime \prime}$ NiTi archwires, with and without aesthetic coating, when coupled with monocrystalline alumina brackets. The static frictional force was determined using a testing machine for measuring compression and tension forces. The results showed a variation of static frictional forces depending on the type of archwire used. Uncoated archwires have produced the lowest static frictional forces. Partially aesthetic coated archwires have generated lower static frictional forces than fully aesthetic coated ones. Fully aesthetic coated archwires have produced the highest static frictional forces, but no significant differences were noted between archwires with polymer and epoxy resin coating.
\end{abstract}

Keywords: aesthetic fixed orthodontic appliance, static frictional force, coated archwire, monocrystalline alumina bracket

An orthodontic appliance is a device that applies force to the teeth and their supporting structures, to produce changes in the relationship of the teeth and the skeletal structures, and to control their growth and development, by using gentle force [1]. Lately, the number of adults seeking orthodontic treatment has been steadily growing [2]. Consequently, this has led to an increased demand for fixed orthodontic appliances that are both aesthetic and efficient in terms of treatment duration. Dental materials used in the treatment of oral pathology have to fulfill several properties, such as biocompatibility [3,4], homogeneity [510], strength [2,11-21], aesthetics [1], corrosion and degradation resistance [22-25] indifferent of the general status health of the patient $[26,27]$.

The first aesthetic brackets were made of plastic materials (polycarbonate) and marketed in the early 1970s, followed by alumina and zirconia ceramic brackets $[28,29]$. More recent technological advances have also targeted another component of the fixed orthodontic appliance - the orthodontic archwire. Nowadays, various companies produce aesthetic orthodontic archwires that differ in respect of the manufacturing processes and materials used. Transparent non-metallic archwires are increasingly researched, yet aesthetic coated metallic archwires remain most clinically popular $[30,31]$. However, the behavior of these products during fixed orthodontic therapy is not as well investigated as that of aesthetic brackets.

When analyzing the mechanics of a fixed orthodontic system (bracket-archwire-ligation) various forces arise, of which the static frictional force is one of the most important variables. Superficial dental erosion emerges as results of physical factors as well as of certain chemical factors [32].

The aim of this study is to evaluate static frictional forces generated by different types of round 0.016 " NickelTitanium (NiTi) archwires, with and without aesthetic coatings, when coupled with monocrystalline alumina brackets.

\section{Experimental part \\ Material and method}

The study group consisted of 0.016 "NiTi wires with ovoid arch form. We chose these archwires because of their routine use in the leveling and aligning phase of orthodontic treatment with fixed appliances $(0.022 \times 0.028$ " bracket slot).

Thermally activated NiTi archwires have been excluded from the study so that temperature variation would not alter their behavior during the experiments. In respect of the type and coverage of the aesthetic coating this study considered the following archwires: two fully aesthetic coated archwires (one with polymer (FC1) coating and another with epoxy resin (FC1) coating) (Fig. 1), a partially aesthetic coated archwire (PC) with a tooth-coloured plastic layer covering only the vestibular surface of the archwire and an uncoated archwire (UC).

The most detailed information regarding the coating material was provided by the manufacturer of the polymer coated archwire. This polymer coated wire has a doublelayered coating structure on its entire surface with a thin

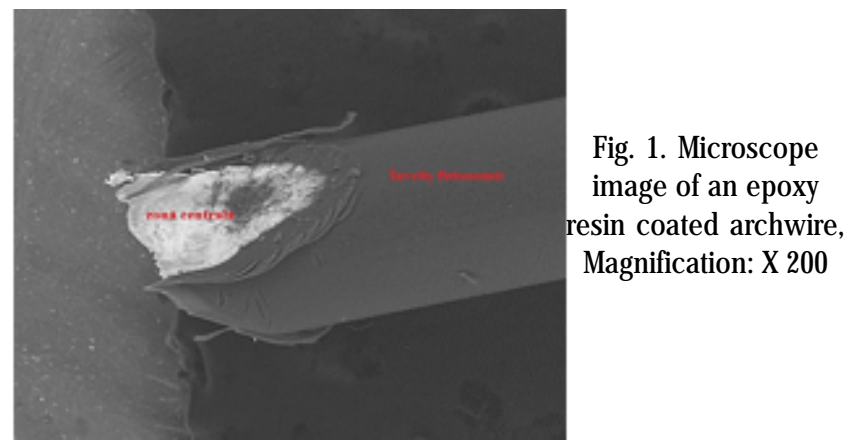


inner silver layer and an outer bio-polymer coating, resistant to corrosion and staining [33].

The archwires were tested with monocrystalline alumina brackets (MCS) from three different manufacturing companies, with MBT prescription and 0.022 " slot. We chose MCS brackets because they are among the most used aesthetic brackets due to their translucency. The brackets (form upper right central incisor to upper rightsecond premolar) were fixed on standardized maxillary models with a light curable orthodontic adhesive. In order to reduce bonding errors that could influence the frictional resistance, brackets were aligned under the guiding of a $0.021 \times 0.025$ " stainless steel rectangular archwire. Before each test the archwire was secured to the brackets with elastomeric ligatures (diameter $0.120^{\prime \prime}$.

The static frictional force was determined using a universal testing machine for measuring compression and tension forces with a maximum capacity of $500 \mathrm{~N}$ (Test Stand HV-500N, Schmidt Control Instruments), within the Faculty of Mechanical Engineering and Mechatronics, University Politehnica of Bucharest (Fig. 2) [34,35].

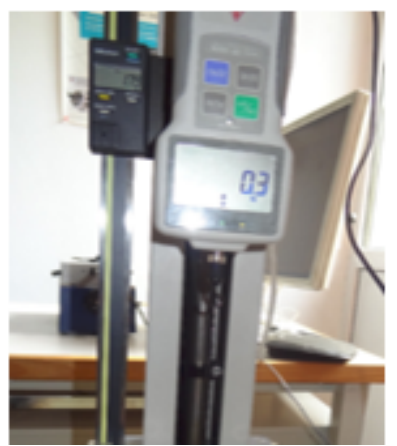

Fig. 2. Testing machine used to determine the static frictional force

For each experiment, a computer connected to the testing machine recorded the frictional forces, which were expressed in Newton (N). The maximum value recorded immediately before archwire movement was considered to be the static frictional force. All the experiments were performed by the same team of operators under the same conditions, and repeated six times using new orthodontic archwires for every test.

The data were entered into a Microsoft Excel 2010 document and statistically analysed using SPSS program (SPSS, Chicago, IL). The descriptive statistics included means and standard deviations, tests that verify the normality of distribution and that compare the frictional forces among the different types of archwires. Statistical significance was considered for a $p$-value $\leq 0.05$.

\section{Results and discussions}

The results of our experiments showed a variation of static frictional forces with the type of archwire used ( Table 1). The Shapiro-Wilk test for normality revealed a non- parametric distribution of the recorded frictional forces. Uncoated archwires generated the lowest values of static frictional forces (Table 1).

The Dunn-Bonferroni tests show statistically significant differences between the uncoated and both fully aesthetic coated archwires (Table 2).

Although not identical from a methodology point of view, other research studies had similar results, associating low frictional forces with uncoated archwires. A study conducted by Al-Ghroosh et al. (2018) on round 0.018" NiTi archwires pointed out that uncoated wires produced smaller frictional forces than aesthetic archwires, but differences were not statistically significant $[36,37]$.

Partially coated archwires produced lower static frictional forces than fully coated aesthetic archwires. The values generated by partially coated archwires were higher than those produced by uncoated archwires, but differences between the two were statistically insignificant (Table 2). According to the Dunn-Bonferroni test there are statistically significant differences between the partially coated archwires and aesthetic archwires with polymer coating. These results could be explained by the incomplete coating coverage (only on the vestibular surface) of the partially coated archwires, thus contact between bracket and wire occurs in part on uncoated areas. Our findings are similar to those of Rudge etal. [38], which observed in their study on different types of 0.016 " aesthetic archwires, that some partially coated archwires are associated with lower kinetic frictional forces than fully coated wires.

Fully aesthetic coated archwires produced the highest static frictional forces (Table 2). Of these, aesthetic archwires with polymer coating generated static frictional forces superior to those with epoxy resin coating, but differences between the two types of aesthetic archwires were not significant ( Table 2). Other studies also indicate higher static frictional force values for aesthetic archwires, compared to uncoated archwires [38-42]. These results could be explained by the proneness of aesthetic coating to scratches and peeling during orthodontic sliding mechanics $[39,40]$ or by adhesive forces between the bracket and aesthetic archwire surfaces [40]. The results of the study conducted by Al-Ghroosh et al. [36] also reveal lower frictional forces for epoxy resin coated archwires than for other types of aesthetic archwires, but the values were not significantly different. Research by Ryu S.H. etal. [43] demonstrates that polymer coated archwires, having the most important surface roughness, determine higher frictional forces than those with epoxy resin or teflon coating.

However, there are also studies that are discordant with previous observations [44-46]. These advocate that new, unused aesthetic archwires can generate lower frictional forces than uncoated archwires, probably due to the different degrees of surface roughness of various bracket-

\begin{tabular}{|c|c|c|c|c|c|}
\hline Bracket & $\mathrm{UC}$ & PC & FCl & $\mathrm{FC} 2$ & p \\
\hline $\operatorname{MCS}(p<0.001)^{*}$ & $4 \pm 0.395$ & $4.616 \pm 0.559$ & $7.116 \pm 1.157$ & $6.033 \pm 1.301$ & $<0.001^{* *}$ \\
\hline
\end{tabular}

\begin{tabular}{|c|c|c|c|c|}
\hline Archwire $^{*}$ & UC & PC & FC1 & FC2 \\
\hline$U C$ & - & 0.267 & $<0.001$ & $<0.001$ \\
\hline$P C$ & 0.267 & - & $<0.001$ & 0.159 \\
\hline$F C 1$ & $<0.001$ & $<0.001$ & - & 0.243 \\
\hline$F C 2$ & $<0.001$ & 0.159 & 0.243 & - \\
\hline
\end{tabular}

*Dunn-Bonferroni Test
Table 1

STATIC FRICTIONAL FORCE VALUES AT THE BRACKETARCHWIRE INTERFACE 
archwire couples [47]. Characterization of different archwires from the point of view of their mechanical properties is extremely important in understanding their behavior in a clinical situation [43]. It is important to note that experimental conditions cannot reproduce the complex interactions occurring in the oral cavity, but can provide a scientific basis for comparing the aesthetic coated archwires.

\section{Conclusions}

Our experiments showed a variation of static frictional forces depending on the type of archwire used. Thus:

- Uncoated archwires have generated the lowest static frictional forces. Although less aesthetic, these archwires can be considered the most efficient choice in terms of sliding mechanics of a fixed orthodontic system using monocrystalline alumina brackets;

-Partially aesthetic coated archwires have been associated with lower static frictional forces than fully aesthetic coated ones and could represent a better therapeutic alternative compared to fully aesthetic coated archwires;

-Fully aesthetic coated archwires have produced the highest static frictional forces. No significant differences were noted between archwires with polymer and epoxy resin coating.

Acknowledgements: The microscope image was obtained courtesy of Prof. Univ. Dr. Ing. Adrian Volceanov, University Politehnica of Bucharest;

** The experiments were carried out with the support of Conf. Univ. Dr. Ing. Ciprian-Ion Rizescu, University Politehnica of Bucharest;

\section{References}

1.BECHIR, A., PACURAR, M., BECHIR, E.S., COMANEANU, R.M., CHIBELEAN CIRES, M., MARIS, M., BARBU H.M., Mat. Plast, 51, no. 1, 2014, p. 57-61.

2.BOTOACA, O., BECHIR, E.S., COMANEANU, R.M., COMAN, S., TARCOLEA, M., DRAGUS, D., Rev. Chim. (Bucharest), 70, no. 1, 2019, p. 84-86.

3.COMANEANU, R.M., HANCU, V., BARBU, H.M., COMAN, C., COTRUT, C.M., TÂRCOLEA, M., HOLICOV, A.M., ORMENISAN, A., Rev. Chim. (Bucharest), 66, no. 3, 2015, p. 312-315.

4.DRAGUS, L., GHERGIC, D.L., COMANEANU, R.M., BECHIR, A., COMAN, C., BOTOACA, O., Rev. Chim. (Bucharest), 70, no. 2, 2019, p. $610-613$

5.BERESESCU, F.G., HANCU, V., MUCENIC, S.G., COSARCA, A.S., COMANEANU, R.M., ORMENISAN, A., Mat. Plast, 52, no. 2, 2015, p. 272274.

6.TARCOLEA, M., HANCU, V., MICULESCU, F., SMATREA, O., COMAN, C., COMANEANU, R.M., ORMENISAN, A., Rev. Chim. (Bucharest), 66, no. 8, 2015, p. 1143-1146.

7.HANCU, V., COMANEANU, R.M., COMAN, C., TARCOLEA, M., BARBU, H.M., BECHIR, A., MICULESCU, F., LOREAN, A., Rev. Chim. (Bucharest), 66, no. 9, 2015, p. 1327-1330.

8.POPESCU, A.I., TARCOLEA, M., OPRISAN, V., COMANEANU, R.M., et al, Rev. Chim. (Bucharest), 66, no.10, 2015, p. 1671-1674.

9.POPESCU, A.I., GIURESCU DUMITRESCU, R.A., OPRISAN, V., COMANEANU, et al, Rev. Chim. (Bucharest), 67, no.11, 2016, p. 21902192.

10.PATROI, D.N., MOLDOVAN, M., CERNUSCA-MITARIU, S., HANCU, V., COMANEANU, R.M., BARBU, H.M., Mat. Plast, 53, no.4, 2016, p. 646652.

11.MAHMOUD, E, PACURAR, M., BECHIR, E.S., MARIS, M., OLTEANU, C., DASCALU, I.T., MOLDOVAN, M., Mat. Plast. 54, no.1, 2017, p. 141144

12.COMANEANU, R.M., BARBU, H.M., VLASCEANU, D., TARCOLEA, M., Key Engineering Materials, vol 583, 2014, p. 169-174.

13.SZAVA, D.T., BOGOZI, B., SZAVA, I., TARCOLEA, M., COMANEANU, R.M., ORMENISAN, A., Mat. Plast, 52, No. 2, 2015, p. 221-224.

14.ORMENISAN, A., TARCOLEA, M., SUCIU, M., GRIGORAS, R.I., BERESESCU, F.G., VLASCEANU, D., HANCU, V., COMANEANU, R.M., Mat. Plast, 52, no. 3, 2015, p. 373-375.
15.COMAN, C., GHERGIC, D.L., PATROI, D.N., TARCOLEA, M., COMANEANU, R.M., BARBU, H.M., Mat. Plast, 53, no.1, 2016, p.91-94. 16.COSARCA, A.S., GRIGORAS, R., HANCU, V., COMAN, C., COMANEANU R.M., MORARU, L., TARCOLEA, M., ORMENISAN, A., Mat. Plast, 53, no. 1, 2016, p. 135-138.

17.PATROI, D.N., MOLDOVEANU, G., HANCU, V., BOTOACA, 0., COMANEANU, R.M., BARBU H.M., Mat. Plast, 53, no.2, 2016, p. 215221.

18.SZAVA, D.T., SZAVA, I., ORMENISAN, A., COMANEANU, R.M., HANCU, V., SZEKELY, M., Mat. Plast, 53, no. 4, 2016, p. 749-751.

19.BERESESCU, G., ORMENISAN, A., COMANEANU, R.M., CARP VELISCU, A.M., MANEA, M.M., ION. R., Mat. Plast, 55, no.1, 2018, p. 4245.

20.DRAGUS, L., TINU, A.S., COMAN, C., COMANEANU, R.M., GHERGIC, D.L., Rev. Chim. (Bucharest), 69, no.9, 2018, p. 2594-2596.

21.COMANEANU, R.M., BORDEA, L.E., PARASCHIV, V., BOTOACA, O., BECHIR, F., TARCOLEA, M., COMAN, C., TANASE, M., Rev. Chim. (Bucharest), 70, no.1, 2019, p. 74-77.

22.HANCU, V., COMANEANU, R.M., COMAN, C., FILIPESCU, A.G., GHERGIC, D.L., COTRUT, M.C., Rev. Chim. (Bucharest), 65, No. 6, 2014, p. 706-709.

23.COMANEANU, R.M., HANCU, I.D., COMAN, C., HANCU, V., BARBU, H.M., COTRUT, C.M., CERNUSCA MITARIU, M., MARIS, M., Rev. Chim. (Bucharest), 67, no. 10, 2016, p. 1940-1944.

24.DAVID, S., SARBU, I., COTRUT, M.C., COMANEANU, R.M., STOIAN, M., PATROI, D.N., Rev. Chim. (Bucharest), 70, no.3, 2019, p. 863-865. 25.MUCENIC, S.G., FLOREA, A., ORMENISAN, A., COMANEANU, R.M., ZAZGYVA, A., TILINCA, M., Mat. Plast, 53, no.4, 2016, p. 703-707.

26.BARBU, H.M., COMANEANU, R.M., ANDREESCU, C.F., MIJ IRITSKY, E., NITA, T., LOREAN, A., J ournal of Craniofacial Surgery, 26, Issue 6, 2015, p. e558-e559.

27.BOITOR, G.C., CORMOS, G., STETIU, A., STEF, L., ORMENISAN, A., MARIS, M., COMANEANU, R.M., CERNUSCA MITARIU, M., Rev. Chim. (Bucharest), 67, no. 11, 2016, p. 2314-2317.

28.RUSSEL, J.S., J Orthod., 32, No. 2, 2005, p. 146.

29.BRANTLEY, W.A., ELIADES, T., Orthodontic Materials: Scientific and Clinical Aspects, Ed. Georg Thieme, Stuttgart, 2001, p.147.

30.MUGURUMA, T., IIJIMA, M., YUASAC, T., KAWAGUCHID, K., MIZOGUCHI, I., Angle Orthod., 87, No. 4, 2017, p. 610.

31.HARYANI, I., RANABHATT, R., JDMT, 5, No. 3, 2016, p.125.

32.MUCENIC, S. G., CAMARASAN, A.C., FAZAKAS, Z., FULOP, E., ORMENISAN, A., MARIS, M., HANCU, V., TILINCA, M., Mat. Plast, 53, No. 3, 2016, p. 386-390

33.*** http://www.danybmt.com/en/sub/sub02 02.php.

34.RIZESCU, C.I., IONA'CU, G., RIZESCU, D., TRŪFASU, A.O., BOGATU, L., MANEA, E., IEEE International Conference on Mechatronics, 2011, p. 609.

35.*** https://www.hans-schmidt.com/en/produkt-details/test-standhv-500n

36.AL-GHROOSH, D.H., BASIM, A., NAHIDH, M., GHAZI, A., J. Pharm. Sci. \& Res., 10, No. 12, 2018, p. 3310.

37.SITA, D.D., BREZEANU, L., BICA, C., MANUC, D., BECHIR, E.S., HACK, M., PACURAR, M., Rev. Chim. (Bucharest), 69, No. 8, 2018, p. 1992-1995

38.RUDGE, P., SHERRIFF, M., BISTER, D., Eur J Orthod, 37, No. 1, 2015, p. 49 .

39.DICKSON, J.A., JONES, S.P., DAVIES, E.H., Br J Orthod., 21, No. 1, 1994, p. 15

40.SADIQUE, S., RAMAKRISHNA, S., BATCHELOR, A.W., BING, C.H., Wear, 261, nr.10, 2006, p.1121.

41.BANDEIRA, A.M., DOS SANTOS, M.P., PULITINI, G., ELIAS, C.N., DA COSTA, M.F., Angle Orthod., 81, No. 3, 2011, p. 484.

42.KIM, Y., CHA, J.Y., HWANG, C.J., YU, H.S., TAHK, S.G., Korean J Orthod., 44, No. 4, 2014, p.157.

43.RYU, S.H., LIM, B.S., KWAK, E.J ., LEE, G.J ., CHOI, S., PARK, K.H., Scanning, 37, No. 6, 2015, p. 414.

44.POP, S.I., DUDESCU, M., BRATU, D.C., POP, R.V., PETRISOR, M., PACURAR, M., Rev. Chim. (Bucharest), 64, No. 7, 2013, p. 773

45.WICHELHAUS, A; GESERICK, M., HIBST, R., SANDER, F.G., Dent Mater, 21, No. 10, 2005, p. 938.

46.VOUDOURIS, J.C., SCHISMENOS, C., LACKOVIC, K., KUFTINEC, M.M., Angle Orthod., 80, No. 1, 2010, p.188.

47.HUSMANN, P., BOURAUEL, C., WESSINGER, M., JAGER, A., J Orofac. Orthop, 63, No. 3, 2002, p.199.

Manuscript received: 14.05 .2019

http://www.revistadechimie.ro $\quad$ REV.CHIM.(Bucharest) 70 No. $11 \bullet 2019$ 